\title{
THE EFFECT OF WORKING CAPITAL ON FIRM PERFORMANCE
}

\author{
Indah Wahyuni ${ }^{1)}$, Seto Sulaksono Adi Wibowo ${ }^{2)}$ \\ Managerial Accounting Department, Politeknik Negeri Batam \\ Jl. Ahmad Yani, Batam Centre, Batam 29461, Indonesia \\ ${ }^{1)}$ E-mail: indah27wahyuni@gmail.com \\ ${ }^{2)}$ E-mail: seto@polibatam.ac.id
}

\begin{abstract}
This study aims to examine the effect of working capital on firm performance. To implement the operating activities, the company should be able to manage good working capital. Good working capital management can help to enhance the firm performance in the eyes of investors. In this research, working capital is measured using working capital turnover, inventory turnover, days of supply, and cash conversion cycle as independent variables, while firm performance is measured using net profit margin as the dependent variable. The sample of this research is a manufacturing company listed in Indonesia Stock Exchange (IDX) period 2014-2016. Samples were taken by using purposive sampling and meeting the sample criteria. The anaysis technique used in this research is multiple regression analysis by using t test. The results of the study found that working capital turnover, days of supply, and cash conversion cycle negatively affect the performance of the company. While the variable of inventory turnover shows that inventory turnover has a positive effect on firm performance.
\end{abstract}

Keywords: working capital turnover, inventory turnover, days of supply, cash conversion cycle, net profit margin 


\section{Introduction}

Each company has the same goal of improving firm performance every period. In achieving these objectives the company perform various operational activities that require a large cost to generate profits for the company. Costs required by the company can be sourced from working capital, sales, other assets owned by the company, and debt. To determine the effect of the performance of the company's working capital, the company requires a good working capital management. Working capital plays an important role in creating firm performance and competition between companies (Yazdanfar and Oman, 2014).

Company condition can be assessed from financial performance of a company. The financial performance of a company's ability to generate profits as much as possible to manage and control its resources. To do the analysis required some benchmarks in the form of ratios and indexes that connect two financial data with each other. Ratio analysis involves methods of calculating and interpreting financial ratios to analyze and monitor company performance. The ultimate goal is to attract investors to invest in the company. This study uses net profit margin to describe the financial performance of a company. Net profit margin belongs to the profitability ratio group and is used to measure company performance. Net profit margin shows the company's ability to control costs so as to create an efficiency condition. Meanwhile, working capital is measured using working capital turnover, inventory turnover, days of supply, and cash conversion cycle.

There are several problems in the management of cash flow causing high working capital required, length of receivables and low income. To overcome this the company can do several alternatives, including: lower inventory levels, negotiate terms of payment to suppliers, and negotiate with customers related to payment terms. The method of measuring working capital management is the famous cash conversion cycle. A good company is a company that has a low cash conversion cycle value. Inventory is an important element in manufacturing companies, so companies will be at risks if the consumer's wishes can't be satisfied. This will be bad for the company, because indirectly the company to lose the opportunity to gain the benefits that should be obtained. Inventory control in a company can facilitate or facilitate the operation of the company. The faster the inventory turnover the higher the performance of the company. This is in line with research conducted by Wau (2017) who found a positive influence between inventory turnover on profitability. However, the length of time required by companies ranging from producing to goods or products to the hands of the end consumer also has a significant effect on the performance of the company. There are several empirical studies measuring the effect of cash conversion cycle, working capital turnover and inventory turnover on profitability or corporate performance that has been done both inside and outside the country. Such as studies conducted by Yasdanfar and Ohman (2014); Anser and Malik (2013); Nwude et al (2018) found a negative effect of cash conversion on profitability. Another study conducted by Gill et al (2010) states that the cash conversion cycle has a positive effect on company performance. Zuniarti et al (2017) conducted a study related to the influence of working capital turnover on profitability. The results of this study concluded that the working capital turnover significantly affects net profit margin. In contrast to the results of previous research, Ismiati (2013) which concluded working capital turnover negatively affect profitability. The big difference in the results of previous studies such as research Amdani and Desnerita (2014) stated that working capital turnover has a positive and significant effect on profitability.

Inconsistency research also applies to research related to inventory turnover. As the results of research conducted by Mappanyuki and Sari (2017) which states that inventory turnover significant effect on profitability as measured by net profit margin. The opposite result was obtained by Sari and Budiasih (2014) who found that inventory turnover had no significant effect on company profitability. Based on the explanation on the introduction, the problem in this research is whether the working capital turnover, inventory turnover, days of supply and cash conversion 
cycle affect the firm performance as measured by net profit margin.

\section{Theoretical}

\subsection{Firm Performance}

According to IAI (Indonesian Institute of

Accountants), financial performance is the company's ability to manage and control the company's resources. According to Agnes (2005), the function of financial performance is to assess the condition of the company, where the analysis requires several benchmarks in the form of ratios and indexes that connect two financial data with each other. According to Gitman and Zutter (2012), ratio analysis involves methods of calculating and interpreting financial ratios to analyze and monitor company performance. The basic input for ratio analysis is the income statement and the company's balance sheet. Financial ratios can be divided into five basic categories: liquidity, activity, debt, profitability, and market ratio.

An indicator that can be used to evaluate profitability related to sales is the common-size income statement. The common-size is an indicator used to compare company performance over the years. The common size income statement analysis makes it easier to see what is driving a company's profits, and compare that performance to its peers. Three profitability ratios derived directly from the common-size income statement are gross profit margin, operating profit margin, and net profit margin. In this research only use one indicator only that is net profit margin. This ratio is used to measure the company's ability to generate net income (net income) from the main operating activities of the company. The higher net profit margin the better operation of an enterprise This ratio is used to measure the company's ability to generate net income (net income) from the main operating activities of the company. The higher net profit margin the better operation of a company (Mappanyuki and Sari, 2017).

\subsection{Working Capital}

Every company needs working capital to cover the company's operational activities. Working capital must be kept rotating as long as business activities. This working capital is usually used to pay the salaries of employees, wages of laborers, buy raw materials, and other expenditures used for the operations of the company. Working capital should be available in sufficient quantities to enable the company to operate economically and be able to cope with critical or emergency situations without threatening the company's financial condition (Fitri et al, 2016). The period of working capital turnover begins when cash is invested in the components of working capital up to the time it returns to cash. The shorter the period means the faster the working capital turnover and the high efficiency of using working capital of a company (Ismiati, 2013).

According to Brealey and Myers (2001), there are four important things in the production cycle that affect the company's investment in working capital. The company started the cycle by buying raw materials, but didn't pay them immediately. This delay is called the period of accounts payable. The company processes the raw materials and then sells the finished goods. The delay between the initial investment in inventory and the date of sale is called the inventory period. After the company sells the goods, the customer pays their bills. The delay between the date of sale and the date when the paid company is called the period of accounts receivable.

3 Results and Discussion

\section{Research Method}

Data Types and Sources

This research uses quantitative methods to test hypotheses. This method aims to conclude the test results of the influence of working capital on the performance of the company. Data type used in this research is secondary data with cross section method. The research data is obtained from the financial statements of 78 manufacturing companies listed on the Indonesia Stock Exchange from 2014 until 2016. The company's financial statements are downloaded from IDX website (www.idx.co.id), and the website of each company. 
Dependent Variabel

Dependent variable in this research is company performance measured by using net profit margin. Increase or decrease in net income (net income) has a significant effect on the performance of the company, although not the only determinant. Company performance is regarded as one of the benchmarks against the current condition of the company that can increase or decrease the number of investors and capital coming into the company. The equation used to calculate the net profit margin is:

$$
N P M=\frac{\text { Income After Tax }}{\text { Net Sales }}
$$

Independent Variabel

The independent variables of this study were measured using working capital turnover, inventory turnover, days of supply and cash conversion cycle.

\section{Working Capital Turnover}

The length of the working capital turnover depends on how long the rotation period of each component of the working capital. To assess the efficiency of working capital can be used a ratio often called working capital turnover. Working capital turnover is a ratio that shows the relationship between working capital and sales that can be obtained by the company. The equation used to calculate the working capital turnover is:

$$
W C T=\frac{\text { Sales }}{\text { Current Asset }- \text { Current Liabilities }}
$$

\section{Inventory Turnover}

Inventory turnover is the ratio used to find out how many times in a given period a company sells inventory. The equation used to calculate the working capital turnover is:

$$
\text { ITO }=\frac{\text { Cost Of Good Sold }}{\text { Average Inventory }}
$$

Days of supply is used to measure the length of time required by companies from selling until the goods/services to consumers. The equation used to calculate the days of supply is:

$$
\text { DoS }=\begin{aligned}
& \text { Average Inventory } \\
& (\text { COGS }) /(365 \text { days })
\end{aligned}
$$

\section{Cash Conversion Cycle}

The shorter the time it takes, the better for a good supply chain and the company usually has a short cash conversion cycle. According to Evans and Lamoureux (2010), the relationship between the cash conversion cycle and these three components is:

$$
C C C=D S O+D I I-D P O
$$

The following components are in cash conversion cycle:

1. Days Sales Outstanding (DSO), which is the average number of products sold with the receipt of cash payments from sellers. The equation used to calculate the days sales outstanding is:

$$
\text { DSO }=\frac{\text { Account Receivable }}{\text { Sales }} \times 365
$$

2. Days of Inventory (DOI), which is the average inventory turnover speed. The higher the value of DOI the faster the inventory turns. The equation used to calculate the days of inventory is:

$$
D O I=\begin{gathered}
\text { Inventory } \\
\text { Cost Of Good Sold }
\end{gathered} \times 365
$$

3. Days Payables Outstanding (DPO), which is the average number of days the company needs to pay or make payment of trade payables to the supplier. The high value reflect the company's low paying ability. The equation used to calculate the days payables outstanding is:

Days Of Supply 


$$
\text { DPO }=\frac{\text { Account Payable }}{\text { Cost Of Good Sold }} \times 365
$$

\section{Hypothesis}

According to Riyanto (2008), low working capital turnover indicates the existence of excess working capital which may be caused by low turnover of inventory, accounts receivable, or cash balance that is too big. Thus, the higher the inventory turnover the higher the turnover of a form's working capital. Inventory turnover indicates that each stock sold is equivalent to the money invested in buying the stock.

The more often stocks are sold, the more often the money goes into the company. If the company sells the inventory above the cost of the stock, then certainly the company will get a profit from the sale. Therefore, higher sales will increase the company's profit.

Days of Supply indicates how long the dosage will be available at any time. Days of supply is also often assumed as the waiting time for the stock to be re-owned. The faster the preparation is available the faster the company can sell its supply. The faster the occurrence of sales the faster the company gets revenue and leads to the company's profit. Shorter cash conversion cycles indicate that the company receives cash before paying to the supplier so that the company is able to manage its cash flow more efficiently. A shorter cash conversion cycle will impact on cost savings and maximize profits. So, the shorter cash conversion cycle will negatively affect the profit rate of a company. Based on the above explanation, the hypothesis in this study as follows:

H1: Working capital turnover has a positive effect on net profit margin

$\mathrm{H} 2$ : Inventory turnover has a positive effect on net profit margin

H3: Days of supply has a positive effect on net profit margin

H4: Cash conversion cycle has a negative effect on net profit margin

Based on the above hypothesis, the model in this study can be seen in figure 1 as follows:

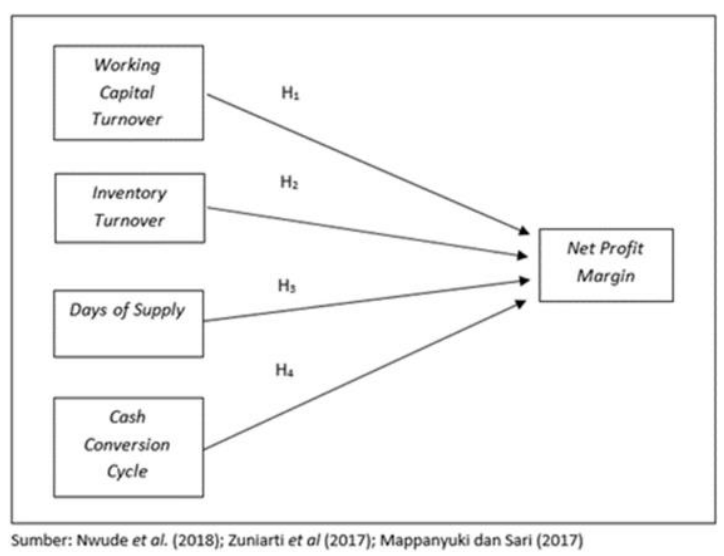

Figure 1

Sampling Techique

The population of this study are all companies listed on the Indonesia Stock Exchange (IDX) for the period 2014-2016. Sample were taken by using purposive sampling and meeting the sample criteria. The criteria of the companies used as samples in this study are as follows:

1. Manufacturing companies listing on the Indonesia Stock Exchange (IDX) during the period 2014-2016.

2. Manufacturing companies that publish annual reports during the period 2014-2016.

3. Manufacturing companies that use Rupiah (Rp). 


\section{Data Collection Techique}

In this study using data collection techniques in the form of data base. The database used comes from the source of Indonesia Stock Exchange (IDX) or contained in the official website www.idx.go.id. The data obtained is crosssection data. Crosssection data is data from the observation result of different entity where variable is measured at one point same time (Ghozali, 2012).

\section{Data Processing Method}

Secondary data in the form of balance sheets, income statements and notes to the financial statements contained in the annual report obtained through the database as described previously requires the steps of data processing:

1. Determine the variables to be included in the cross table or frequency table. In this stage, the authors define the variables that will be examined to facilitate later in the tabulation.

2. Tabulating, which is data processing done by grouping or entering data into the table. Tabulation results are a brief description of the results of the study. Tabulation is done to facilitate in terms of observation and data analysis.

3. Editing, which is checking the data to see whether the error or wrong data that must be fixed.

\section{Analysis Data Technique}

This study uses statistical data analysis. Data analysis tool used is multiple linear regression model. The rule using this model is that there is no multicolonierity and heteroscedasticity. The next step that must be done is to test the hypothesis that has been determined. The data processing is done by SPSS. The following is a statistical test conducted in the study.

\section{Classical Assumption Test}

Multiple regression testing can be done after passing from the classical assumption test that includes data normality test, multicolonierity test and heterokedastisity test.

1. Normality test, is used to see whether the residual value is normally distributed or not. Data is normally distributed if significance value $>0,05$. Conversely, the data is not normal if the value of significance $<0.05$.

2. Multicolonierity test, is used to test whether in the regression model found the existence of linear correlation between independent variables. If there is a linear correlation between independent variables then it can be said there are indications of multicollinearity. The main rule to pass from multicollinearity test if independent variable has tolerance value $>0,10$ or VIF value $<10,00$.

3. Heteroscedasticity test, is used to test whether in the regression model there is a variance inequality of the other residual observations. If the residual of an observation to another observation remains then it is called homocedasticity. However, if the residuals from one observation to another observation are different then it is called heteroscedasticity. Based on the glejser test, no heteroscedasticity occurs when the significance value is $>0.05$.

\section{Regression Analysis}

Regression analysis is used to predict dependent variable (Y) if known independent variable (X). If a dependent variable is influenced by more than one independent variable, then to perform the analysis required multiple regression analysis. Regression analysis used in this study is multiple regression analysis. Multiple regression analysis is useful to find the influence of two independent variables to the dependent variable. The form of regression test equation in this research is as follows:

Net Profit Margin $=\alpha+\beta 1 \mathrm{WCT}+\varepsilon \ldots \ldots \ldots \ldots \ldots . . .$.

Net Profit Margin $=\alpha+\beta 2 \mathrm{ITO}+\varepsilon \ldots \ldots \ldots \ldots \ldots . .$.

(2)

Net Profit Margin $=\alpha+\beta 3 \mathrm{DoS}+\varepsilon$

(3) 
Net Profit Margin $=\alpha+\beta 4 C C C+\varepsilon \ldots \ldots \ldots \ldots \ldots$. (4)

Where net profit margin is a dependent variable (predicted value); $\beta 1, \beta 2$ is a working capital turnover, inventory turnover, days of supply, and cash conversion cycle as independent variables. Meanwhile, $\alpha$ is the constant value and $\beta$ is the regression coefficient (value increase or decrease) and $\varepsilon$ is the error term.

Partial Test (Statistic Test)

Partial test (statistical t-test) is used to find the independent variable partially or individually has an effect on the dependent variable with the assumption of other variables constant. Ghozali (2012) states that if the probability significance value $<5 \%$ means there is a significant influence between the variables partially with the dependent variable.

\section{Results and Discussion}

Based on the descriptive statistic in table 2 (attachment), it is known that from the 184 sample companies obtained the minimum value of net profit margin of 0.0002 is PT Voksel Electric Tbk in 2015. The amount of net profit generated by the company is very small compared to other companies caused by the declining of company performances. In 2014, PT Delta Djakarta Tbk has the highest net profit margin of 0.3276, which means that the net profit earned has the highest net income so it can be concluded that the company's performance in that period has increased. The average net profit margin is 0.073754 and the standard deviation is 0.0607359 , meaning that the difference in sample data is 0.0607359 from the mean and the mean is greater than the standard deviation. This indicates a good result because the smaller the standard deviation value, the better the data spread.

Working capital turnover has a minimum value of 0.67 , the maximum working capital turnover is 237.04 .

The average working capital turnover of 9,1292 indicates the average working capital turnover period of the sample company. The low turnover period of working capital illustrates that the excess of working capital may be caused by low inventory and receivable turnover, or cash balance is too large. Excessive cash balances or low inventory turnover and receivables can cause the company difficulty in improving the company's performance. The standard deviation value of working capital turnover of 21.85900 shows the average deviation of working capital turnover. The smaller the standard deviation value then the diversity of data used as the sample is getting smaller.

Inventory turnover has a minimum value of 1.13 times and the maximum value of inventory turnover is 24.28 times. The high period of inventory turnover illustrates that the company's ability to improve the company's performance. The average value of inventory turnover is 4.7817 times which shows the average number of times the inventory can be converted into cash. The standard deviation value of inventory turnover of 3.46642 shows the average deviation of inventory turnover. The smaller the standard deviation value then the diversity of data used as the sample is getting smaller.

Days of supply has a minimum value of 15 days and the maximum value of days of supply is 322 days. The low period of the days of supply illustrates the speed with which firms convert working capital in inventory to cash back. While the average days-of-day value of 108.01 days indicates the average number of days the sample company needs to convert the inventory to cash back. The longer the period of days of supply, the lower inventory turnover rate. The standard deviation value of days of supply of 61.901 indicates the average deviation days of supply. The smaller the standard deviation value then the diversity of data used as the sample is getting smaller.

Cash conversion cycle has a minimum value of 0.03 and a maximum value of 410 . While the average value of cash conversion cycle is 133.3702 and the value of standard deviation of 83.32408 means that the difference in sample data spaced by 83.32408 from the average value and greater than the standard deviation. This indicates a good result because the smaller the standard deviation value, the smaller the sample data.

\section{Hypotesis Test}


In this research the multiple regression hypothesis test used is $\mathrm{t}$ test. This test is used to determine the independent variables partially or individually has an effect on the dependent variable with the assumption that other variables are constant.

Hypotesis 1

The first hypothesis proposed in this study states that working capital turnover has a positive effect on net profit margin. This study used 78 companies as samples that were processed using SPSS and the results are presented in table 3 (attachment). The result of the statistical test $\mathrm{t}$ the first equation model shows that the regression coefficient value of working capital turnover $(\mathrm{X} 1)$ is -0.019 , it means that if the working capital turnover variable increases by $1 \%$ it will decrease the net profit margin value by 0,091 . Based on the above table the value of $\beta$ owned by -.019 and significance value of $0.000 \quad(<0.05)$, it can be concluded that $\mathrm{H} 1$ significant but not supported. The adjusted R2 of $88 \%$ indicates that the dependent variable, net profit margin, can be explained by the independent variable that is working capital turnover. While the remaining $12 \%$ is explained by other variables outside of this model.

The results have been tested with classical assumptions. VIF value 1,059 indicates there is no multicollinearity because VIF value less than 10.00 is still within the tolerance limit. Glejser test value of 0.732 indicates that there is no heterocedasticity because the value is above the standard 0.05 is still within the limits of tolerance. The normality test using the 0.200 kolmogorov-smirnov test indicates that the data is normally distributed. The results of the first hypothesis testing have passed the classical assumption.

\section{Hypotesis 2}

The second hypothesis proposed in this study states that inventory turnover has a positive effect on net profit margin. This study used 78 companies as samples that were processed using SPSS and the results are presented in table 4 (attachment). The result of $t$ test of second equation model shows that regression coefficient value of inventory turnover (X2) is 0,032 , it means that if inventory turnover variable increase by $1 \%$ it will increase net profit margin value equal to 0,032 . Based on the above table the value of $\beta$ owned by .032 and the significance value of 0.011 $(<0.05)$, it can be concluded that $\mathrm{H} 2$ is significant and supported. The adjusted R2 value of $35 \%$ indicates that the dependent variable ie net profit margin can be explained by independent variable that is inventory turnover. While the remaining $65 \%$ is explained by other variables outside of this model.

The results have been tested with classical assumptions. VIF value 6.192 indicates that there is no multicollinearity because VIF value less than 10.00 is still within the tolerance limit. Glejser test value of 0.695 indicated that there is no heterocedasticity because the value is above the standard 0.05 is still within the limits of tolerance. The normality test using the 0.200 kolmogorov-smirnov test indicates that the data is normally distributed. The results of the second hypothesis testing have passed the classical assumption.

\section{Hypotesis 3}

The third hypothesis proposed in this study states that inventory turnover has a positive effect on net profit margin. This study used 78 companies as samples processed by using SPSS and the results are presented in table 5 (attachment). The result of $t$ test of the third equation model shows that the regression coefficient value of days of supply (X3) is -0.007 , meaning that if the variable of days of supply increases by $1 \%$ it will decrease the net profit margin value by 0,007 . Based on the above table the value of $\beta$ owned by -.007 and significance value of $0.023 \quad(<0.05)$, it can be concluded that $\mathrm{H} 3$ is significant but not supported. Adjusted R2 value of $28 \%$ indicates that the dependent variable ie net profit margin can be explained by independent variable that is days of supply. While the remaining $72 \%$ is explained by other variables outside of this model.

The results have been tested with classical assumptions. The VIF value of 7,729 indicates that there is no multicollinearity because VIF value less 
than 10.00 is still within the tolerance limit. Glejser test value of 0.805 indicated that there is no heterocedasticity because the value is above the standard 0.05 is still within the limits of tolerance. The normality test using the 0.200 kolmogorov-smirnov test indicates that the data is normally distributed. The results of the third hypothesis testing have passed the classical assumption.

Hipotesis 4

The fourth hypothesis proposed in this study states that inventory turnover has a positive effect on net profit margin. This study used 78 companies as samples processed by using SPSS and the results are presented in table 6 (attachment). The result of t test of the first equation model shows that the value of the cash conversion cycle variable coefficient (X4) is -0.006 , meaning that if the cash conversion cycle variable increases by $1 \%$ it will decrease the net profit margin value by 0,006 . Based on the above table the value of $\beta$ owned by -.006 and significance value of 0.014 $(<0.05)$, it can be concluded that $\mathrm{H} 4$ is significant and supported. The adjusted R2 of 33\% indicates that the dependent variable, net profit margin, can be explained by independent variable ie cash conversion cycle. While the remaining $67 \%$ is explained by other variables outside of this model.

The results have been tested with classical assumptions. VIF value 2.939 indicates that there is no multicollinearity because VIF value less than 10.00 is still within the tolerance limit. Glejser test value of 0.743 indicates that there is no heteroscedasticity because the value is above the standard 0.05 is still within the limits of tolerance. The normality test using the 0.200 kolmogorov-smirnov test indicates that the data is normally distributed. The results of the fourth hypothesis testing have passed the classical assumption.

Data Analysis

Based on result of hypothesis test between independent variable and dependent variable that is working capital turnover, inventory turnover, days of supply and cash conversion cycle as independent variable and net profit margin as dependent variable. Summary of statistical test results can be seen in table 1 as follows:

Table 1 Summary of Statistical Test Results

\begin{tabular}{|c|c|c|c|c|}
\hline & Hypotesis & Sig. $(5 \%)$ & $\beta$ & Result \\
\hline $\mathrm{H}_{4}$ & $\begin{array}{l}\text { Working capital turnover } \\
\text { positively affects net profit } \\
\text { margin }\end{array}$ & 0.000 & .019 & $\begin{array}{l}\text { Not supported because } \\
\text { beta is negative }\end{array}$ \\
\hline $\mathrm{H}_{2}$ & $\begin{array}{l}\text { Inventory tumover positively } \\
\text { affects net profit margin }\end{array}$ & 0.001 & .032 & Supported \\
\hline $\mathrm{H}_{3}$ & $\begin{array}{l}\text { Days of supply positively } \\
\text { affects net profit margin }\end{array}$ & 0.023 & .007 & $\begin{array}{l}\text { Not supported because } \\
\text { beta is negative }\end{array}$ \\
\hline $\mathrm{H}_{4}$ & $\begin{array}{l}\text { Cash conversion } \\
\text { negatively affects net } \\
\text { margin }\end{array}$ & 0.014 & .006 & Supported \\
\hline
\end{tabular}

The Effect of Working Capital Turnover on Net Profit Margin

Based on the result of regression test which has been described above, it shows that $\mathrm{H} 1$ is significant but negative so that the first hypothesis is not supported. These results indicate that the length of working capital turnover of the company from year to year has decreased, so the sample company takes a long time to turn its working capital into cash back. This can be seen from the average value of the working capital turnover of 9.12 times and the high maximum value of working capital turnover of 237.04 times during the study period. There are several possibilities which could be the cause of the length of working capital turnover of sample companies. First, sales volume has an important role in the turnover of working capital and net profit margin. This can be seen from the equation used to calculate the ratio of working capital turnover and net profit margin has a relationship that is inversely proportional. To obtain the amount of working capital turnover ratio, the company's sales during the study period should be divided by the deductions from current assets and current liabilities. As a result, the greater the sales volume in that period the greater the ratio of working capital turnover. Conversely, if the volume of sales in that period decreases, it will affect the length of rotation of working capital. Different things apply to the net profit margin equation ratio, because to obtain the ratio then the amount of net income in the period should be divided by the volume of sales of the company. This results in a net profit margin ratio will be smaller if the volume of sales 
increasingly large. The net profit earned by the company is the result of a reduction in sales with the necessary operational and administrative costs. As a result, the working capital turnover ratio is not in line with the net profit margin ratio. Thus, the longer the working capital turnover will be the more profits earned.

Second, the condition of the working capital turnover of the sample company is influenced by working capital (current assets and current liabilities) in generating sales. However, the lancer debt held by some sample companies is larger than the current assets, so it can be said the company is in an unhealthy condition. Third, the lack of demand from consumers for companies that apply the make-to-order system. Orders received by the company each period will likely differ according to customer needs and demands. Reduced number of orders received by this company that can be one cause of the length of working capital turnover. Results are similar to research of Fitri, Supriyanto, and Abrar (2016) who found that working capital turnover negatively affects profitability. Similarly, research conducted by Ismiati (2013) found that working capital turnover negatively affect net profit margin. Thus, the increasing amount of working capital can not guarantee or ensure good corporate performance.

Effect of Inventory Turnover on Net Profit Margin Based on the result of the regression test described above, it shows that $\mathrm{H} 2$ is significant and positive so that the second hypothesis is supported. These results indicate that the faster inventory turnover from year to year affect the high performance of the company. These results can also be seen from the average value of inventory turnover that occurred during the study period that is as much as 4.8 times and maximum inventory turnover of 24.2 times. This is because the majority of the manufacturing companies have the necessary inventory, whether raw materials, semifinished goods or finished goods to enable the company to meet the demand arising so that there is no stockpile. This is in line with research conducted by Sufiana and Purwati (2013) and Wau (2017) which states that inventory turnover positively affects the profitability of the company. This is due to the company being able to spin inventory through very high sales, so there is no stockpiling. This high inventory turnover can affect company performance. Thus, the higher the inventory turnover shows the effective and efficient return on working capital that indicates the higher performance of a company.

Effect of Days Of Supply on Net Profit Margin Based on the result of regression test which has been described above, it shows that $\mathrm{H} 3$ is significant but negative so that the third hypothesis is not supported. These results show the length of days the company needs to turn the inventory back into cash. The number of days the company needs to buy raw materials, produce and sell finished goods is a determinant of the significance of the company's performance. This can be seen from the average value of days of supply is long enough that during 108.01 days. While the maximum value required by the company to buy raw materials to sell finished goods that is for 322 days. From these results can be seen that the sample company still takes a long time to perform its operational activities.

The period of days of supply can affect the efficiency of the use of working capital of a company even if the company earns profit or profit. From the results of this study found that the faster the period of days of supply the smaller the profits obtained by the company. This is probably caused by the number of consumers who make transactions on credit. As a result, the company still needs time to receive revenue from sales even if the goods or products have reached the hands of the customer on time. This result is similar to research by Muturi et al (2015) which states that days of supply have a negative and significant effect on the profitability of the company. Thus, the shorter days of supply have not been able to ensure the high performance of a company in turning the working capital back into cash.

The Effect of Cash Conversion Cycle on Net Profit Margin 
Based on the result of the regression test described above, it shows that $\mathrm{H} 4$ is significant but negative so that the fourth hypothesis is supported. These results indicate that the shorter the company's cash conversion cycle from year to year affect the high performance of the company. This result can also be seen from the average value of 133.3 times with a maximum value of 410 times. From the result of the analysis, it can be concluded that the average of the sample company has short cash conversion cycle from year to year. This is because the company has received cash from the sale before it has to pay its obligations to the supplier. The Company may use the cash to finance its day-to-day operations as well as investments in current assets. This is consistent with research conducted by Indradewi and Widyarti (2016) which states that the cash conversion cycle has a negative and significant impact on net profit margin (profitability) and research conducted by Quayyum (2012); Yasdandar and Oman (2014); Anser and Malik (2014) stating that the cash conversion cycle has a negative and significant impact on profitability. This is caused by the ability of the company to turn inventory with a very high sales, so there is no stockpile. This high inventory turnover can affect company performance. A short cash conversion cycle can show that the company's working capital management runs effectively and efficiently, thus indicating good company performance.

\section{Conclusions}

This study aims to provide empirical evidence about the effect of working capital on the performance of companies in manufacturing companies listed on the Indonesia Stock Exchange (IDX) period 2014-2016. Working capital is measured using four variables: working capital turnover, inventory turnover, days of supply, and cash conversion cycle, while company performance is measured by net profit margin. The number of samples used is 78 companies for 3 years so that the final sample is obtained 184 obserrvasi. From the results of hypothesis testing that has been done, it can be concluded as follows:

1. Working capital turnover negatively affects net profit margin, this means the turnover of working capital in a company affect the performance of the company. Thus, the greater the working capital of Rupiah has not been able to determine the performance of a good company.

2. Inventory turnover has a positive and significant effect on net profit margin, this means the higher the inventory turnover in a company will be the higher the company's performance.

3. Days of supply has a negative and significant effect on net profit margin, this means the shorter days of supply the higher the company's performance in turning the working capital of the company into cash back.

4. Cash conversion cycle has a negative and significant effect on net profit margin, it means that short cash conversion cycle can show that the working capital management of the company is running effectively and efficiently, thus indicating good company performance.

\section{Limitations and Suggestions}

The authors found several limitations in this study. Some of the limitations are as follows: The samples in this study are limited to firms in manufacturing listed on the Indonesia Stock Exchange (BEI). Of the 78 companies used as samples, only 184 observations are available that can be used as research data. This is due to the large number of outlier data that must be removed or removed so it can not be used as research data. In addition, the company's performance measurement in this study only uses net profit margin.

Based on the limitations of the problems described above, there are some suggestions for further research as follows: Measuring company performance is recommended to be added with other proxies or add other independent variables that can be used as measures of working capital efficiency, such as receivable turnover, current ratio, other. Further research is expected to increase the number of samples, not only limited to manufacturing companies, but using companies from other sectors that exist in the Indonesia Stock Exchange or add range from the year of research for research to be broader and outlier data can be minimized.

\section{References}

Anser, R., \& Malik, Q. A. (2013). Cash Conversion Cycle and Firms' Profitability - A Study of Listed 
Manufacturing Companies of Pakistan. Journal of Business and Management, 83-87.

Brealey, R. A., Myers, S. C., \& Marcus, A. J. (2001). Fundamental of Corporate Finance (Third ed.). Unitted States of America: McGraw-Hill Higher Education.

Fitri, M. C., Supriyanto, A., \& Abrar. (2016, Maret). Analysis of Debt to Equity, Firm Size, Inventory Turnover, Cash turnover, Working Capital Turnover and Current Ratio to Profitability Company (Study on Mining Companies Listed in BEI Period 2010-2013). Jurnal of Accounting, Vol.2.

Gill, A., Biger, N., \& Mathur, N. (2010). The Relationship Between Working Capital Management And Profitability: Evidence From The United States. Business and Economics Journal, 1-9.

Gitman, L. J., \& Zutter, C. J. (2012). Principle Of Managerial Finance (13th ed.). United States of America: Pearson Education, Inc.

Indradewi, C., \& Widyarti, E. T. (2016, Desember). Analisis Pengaruh Manajemen Modal Kerja Terhadap Profitabilitas Perusahaan Manufaktur Sektor Industri Dasar dan Kimia Go Public Pada Bursa Efek Indonesia (BEI) Periode Tahun 2011-2014. Jurnal Studi Manajemen \& Organisasi 13 (121-130).

Ismiati, N., Puspitaningtyas, Z., \& Sisbintari, I. (2013). Pengaruh Perputaran Modal Kerja Terhaddap Profitabilitas Perusahaan (Studi Pada Perusahaan Manufaktur yang Terdaftar di Bursa Efek Indonesia tahun 2008-2012).

Lamoureux, J. F., \& Evans, T. (2010). Supply Chain Finance: A New Means to Support the Competitiveness and Resilience of Global Value Chains. Supply Chain Finance.

Lazaridis, \& Tryfonidis. (2006). The Relationship Between Working Capital Management and Profitability of Listed Companies in the Athens Stock Exchange. Journal of Financial Management and Analysis, Vol.19, 26-35.

Mappanyuki, R., \& Sari, M. (2017). The Effect Of Sales Growth Ratio, Inventory Turnover Ratio, Growth Opportunity To Company's Profitability (Survey In Indonesia'S Stocks Exchange). Proceedings of 64th ISERD International Conference. Seoul, South Korea.
October). Effect of Inventory Conversion Period on Profitability of Tea Factory in Meru Country, Kenya. International Journal Of EConomic, Commerce and Management, Vol. III(Issue 10), 366-378.

Nwude, E. C., Agbo, E. I., \& Lamberts, C. I. (2018). Effect of Cash Conversion Cycle on the Profitability of Public Listed Insurance Companies. International Journal of Economics and Financial Issue, 111-117.

Quayyum, T. S. (2011). Relationship Between Working Capital Management and Profitability in Context of Manufacturing Industries in Bangladesh. International Journal of Business and Management,, Vol.7.

Sari, N. M., \& Budiasih, I. (2014). Pengaruh Debt To Equity Ratio, Firm Size, Inventory Turnover Dan Assets Turnover Pada Profitabilitas. E-Jurnal Akuntansi Universitas Udayana, 261-273.

Wau, R. (2017). Analisis Efektivitas Modal Kerja dan Pengaruhnya Terhadap Profitabilitas. Journal Of Business Studies, Vol. 2, 61-74.

Yazdanfar, D., \& Öhman, P. (2014). The Impact Of Cash Conversion Cycle On Firm Profitability : An Empirical Study Based On Swedish Data. International Journal of Managerial Finance, 442-452.

Zuniarti, I., Widodo, D. P., \& Lestiningsih, A. S. (2017). Rasio Net Working Capital Turnover Terhadap Rasio Net Profit Margin. Jurnal Administrasi Kantor, 123-132.

Attachment

Table 1 Sample Characteristic

\begin{tabular}{|c|c|c|c|c|}
\hline \multicolumn{2}{|r|}{ Criteria } & \multirow{2}{*}{$\begin{array}{l}2014 \\
132 \\
\end{array}$} & \multirow{2}{*}{$\begin{array}{l}2015 \\
132 \\
\end{array}$} & \multirow{2}{*}{$\begin{array}{l}2016 \\
132 \\
\end{array}$} \\
\hline 1. & $\begin{array}{l}\text { Manufacturing companies listed on the Indonesia Stock } \\
\text { Exchange (IDX) period 2014-2016 }\end{array}$ & & & \\
\hline 2. & Companies that use foreign currency & (28) & (28) & (28) \\
\hline 3. & $\begin{array}{l}\text { Companies that do not publish complete financial } \\
\text { reports or fraudulent financial statements }\end{array}$ & (9) & (7) & (10) \\
\hline & Total Sample (254) & 78 & 66 & 76 \\
\hline \multicolumn{2}{|c|}{ Unusable sample (outlier data) } & (29) & (41) & (32) \\
\hline & Final Sample (184) & 66 & 56 & 62 \\
\hline
\end{tabular}

Table 2 Descriptive Statistic

Muturi, H. M., Wachira, V., \& Lyria, R. K. (2015, 


\begin{tabular}{|l|c|c|c|c|c|}
\hline \multicolumn{1}{|c|}{ Variabel } & $\mathbf{N}$ & Min & Max & Mean & $\begin{array}{c}\text { Standar } \\
\text { Deviasi }\end{array}$ \\
\hline Working Capital Tumover & 184 & .67 & 237.04 & 9.1292 & 21.85900 \\
\hline Inventory Tumover & 184 & 1.13 & 24.28 & 4.7817 & 3.46642 \\
\hline Days Of Supply & 184 & 15 & 322 & 108.01 & 61.901 \\
\hline Cash Conversion Cycle & 184 & .03 & 410.00 & 133.3702 & 83.32408 \\
\hline Net Profit Margin & 184 & .0002 & .3276 & .073754 & .0607359 \\
\hline
\end{tabular}

Source: Data processed with SPSS v23.0

Table 3 Result of Effect Working Capital Turnover on Net Profit Margin

\begin{tabular}{|c|c|c|c|c|c|c|}
\hline \multicolumn{7}{|c|}{ NPM $=\alpha+\beta_{1}$ WCT $+\varepsilon$} \\
\hline \multirow[t]{3}{*}{ Independent Variabel } & \multicolumn{6}{|c|}{ Dependent Variabel } \\
\hline & \multicolumn{6}{|c|}{ Net Profit Margin } \\
\hline & Coefficient & t-statistic & Sig. & $\begin{array}{c}\text { Asymp. } \\
\text { Sig. }\end{array}$ & VIF & $\begin{array}{c}\text { Cji } \\
\text { Glejser }\end{array}$ \\
\hline Constant & .293 & 21.349 & $.000^{*}$ & & & \\
\hline Working Capital Turnover & -.019 & -4.185 & $.000^{*}$ & $.200^{*}$ & 1.059 & .738 \\
\hline \multicolumn{7}{|l|}{ Adjusted R-Squared } \\
\hline \multicolumn{6}{|l|}{ Sig. (F-statictic) } & $.000^{*}$ \\
\hline \multicolumn{6}{|l|}{$\mathrm{N}$} & 184 \\
\hline \multicolumn{7}{|l|}{${ }^{\circ}$ Significance at $5 \%$} \\
\hline $\begin{array}{l}\text { Description: This table p } \\
\text { margin (NPM). The inde }\end{array}$ & the & oth & reh & $\begin{array}{l}\text { endent } \\
\text { (WCT }\end{array}$ & & profit \\
\hline
\end{tabular}

Table 6 Result of Effect Cash Conversion Cycle on Net Profit Margin

\begin{tabular}{|l|c|c|c|c|c|c|}
\hline \multicolumn{7}{|c|}{ NPM $=\alpha+\beta H C C C+\varepsilon$} \\
\hline Independent Variabel & \multicolumn{7}{|c|}{ Dependent Variabel } \\
\cline { 2 - 7 } & \multicolumn{7}{|c|}{ Profit Margin } \\
\hline & Coefficient & t-statistic & Sig. & $\begin{array}{c}\text { Asymp. } \\
\text { Sig. }\end{array}$ & VIF & $\begin{array}{c}\text { Uji } \\
\text { Glejser }\end{array}$ \\
\hline Constant & & & & & \\
\hline Cash Conversion Cycle & -.006 & -2.485 & $.014^{*}$ & $.200^{*}$ & 2.939 & .743 \\
\hline Adjusted R-Squared & 11.576 & $.00 *^{*}$ & & .033 \\
\hline Sig. (F-statictic) & N & & & \\
\hline N & * Significance at 5\% \\
\hline $\begin{array}{l}\text { Description: This table presents the results of hypothesis research 1. Dependent variable is net profit } \\
\text { margin (NPM). The independent variable is the cash conversion cycle (CCC). }\end{array}$ \\
\hline
\end{tabular}

Table 4 Result of Effect Inventory Turnover on Net

Profit Margin

\begin{tabular}{|c|c|c|c|c|c|c|}
\hline \multicolumn{7}{|c|}{$\mathrm{NPM}=\alpha+\beta_{1} \mathrm{ITO}+\varepsilon$} \\
\hline \multirow[t]{3}{*}{ Independent Variabel } & \multicolumn{6}{|c|}{ Dependent Variabel } \\
\hline & \multicolumn{6}{|c|}{ Net Profit Margin } \\
\hline & Coefficient & t-statistic & Sig. & $\begin{array}{l}\text { Asymp. } \\
\text { Sig. }\end{array}$ & VIF & $\begin{array}{c}\text { Uji } \\
\text { Glejser }\end{array}$ \\
\hline Constant & .179 & 6.529 & $.000^{*}$ & $200^{*}$ & & \\
\hline Inventory Turnover & .032 & 2.563 & $.011^{*}$ & $200^{*}$ & 6.192 & .695 \\
\hline \multicolumn{7}{|l|}{ Adjusted R-Squared } \\
\hline \multicolumn{6}{|l|}{ Sig. (F-statictic) } & $.011^{*}$ \\
\hline \multicolumn{6}{|l|}{$\mathrm{N}$} & 184 \\
\hline \multicolumn{7}{|l|}{ - Significance at $5 \%$} \\
\hline \multicolumn{7}{|c|}{$\begin{array}{l}\text { Description: This table presents the results of hypothesis research 1. Dependent variable is net profit } \\
\text { margin (NPM). The independent variable is the inventory turnover (ITO). }\end{array}$} \\
\hline
\end{tabular}

Table 5 Result of Effect Days Of Supply on Net Profit Margin

\begin{tabular}{|c|c|c|c|c|c|c|}
\hline \multicolumn{7}{|c|}{$\mathrm{NPM}=\alpha+\beta 3$ DoS $+\varepsilon$} \\
\hline \multirow[t]{3}{*}{ Independent Variabel } & \multicolumn{6}{|c|}{ Dependent Variabel } \\
\hline & \multicolumn{6}{|c|}{ Net Profit Margin } \\
\hline & Coefficient & t-statistic & Sig. & $\begin{array}{c}\text { Asymp. } \\
\text { Sig. }\end{array}$ & VIF & $\begin{array}{c}\text { Vji } \\
\text { Glejser }\end{array}$ \\
\hline Constant & .313 & 10.359 & $.000^{*}$ & & & \\
\hline Days Of Supply & -007 & -2.298 & $.023^{*}$ & $200^{\circ}$ & 7.729 & .805 \\
\hline \multicolumn{6}{|l|}{ Adjusted R-Squared } & .028 \\
\hline \multicolumn{6}{|l|}{ Sig. (F-statictic) } & $.023^{*}$ \\
\hline \multicolumn{6}{|l|}{$\mathrm{N}$} & 184 \\
\hline \multicolumn{7}{|l|}{${ }^{*}$ Significance at $5 \%$} \\
\hline \multicolumn{7}{|c|}{$\begin{array}{l}\text { Description: This table presents the results of hypothesis research 1. Dependent variable is net profit } \\
\text { margin (NPM). The independent variable is the days of supply (DoS). }\end{array}$} \\
\hline
\end{tabular}

